\title{
Titanium-based composite synthesis in the combustion regime
}

\author{
A. G. KNYAZEVA - Institute of Strength Physical and Material Science SB RAS \\ - anna-knyazeva@mail.ru \\ G. A. PRIBYTKOV - Institute of Strength Physical and Material Science SB RAS - gapribyt@mail.ru \\ Yu. A. CHUMAKOV - Institute of Strength Physical and Material Science SB RAS - chya@ispms.tsc.ru \\ Érkezett: 2018. 01. 07. - Received: 07. 01. 2018. - https://doi.org/10.14382/epitoanyag-jsbcm.2018.13
}

\section{Abstract}

The model of composite synthesis on the base of titanium with inclusions of carbides, borides and silicides is analyzed numerically. It was assumed that synthesis is carried out from the mixtures Ti-C, Ti-B and Ti-Si containing the excess of titanium in comparison with stoichiometric relation of components necessary for the formation of $\mathrm{TiC}, \mathrm{TiB}$ and Ti5Si3. The model is based on the classical ideas of the combustion models with summary reaction. However, it takes into account nonstoichiometric composition of green mixture, dependence of properties on the composition changing during the synthesis and the reaction initiation stage in the igniter. Temperature distribution, conversion level, maximal combustion temperature, reaction zone thickness, and the rate of reaction propagation are determined numerically. The results of the product temperature calculation qualitatively agree with experimental data.

Keywords: composite synthesis, nonstoichiometric mixture, gasless combustion, reaction retardation by reaction product, combustion transition through interface
A. G. KNYAZEVA

Professor, principal researcher of Institute of strength physics and material science SB RAS, professor of Tomsk polytechnic university; scientific interest: macrokinetics, irreversible thermodynamics, mathematical modeling of thermal, mechanical and chemical processes accompanying new material synthesis

G. A. PRIBYTKOV

Principal researcher of Institute of strength physics and material science SB RAS, scientific interest: material science, sintering, combustion

Yu. A. CHUMAKOV Researcher of Institute of strength physics and material science SB RAS; scientific interest: numerical methods; mathematical modeling of thermal-physical processes

\section{Introduction}

Combustion synthesis is an intensively developed scientific field $[1,2]$. Combustion application to modern technologies connects with the possibility to use the energy of chemical reactions and to obtain the final product with slow energy losses. This method attracts attention by numerous researchers. For example, the combustion synthesis of composite with TiCinclusions of various phase composition was carried out in [3]. Composite from Ni, Ti and $\mathrm{B}_{4} \mathrm{C}$ powder blends was synthesized in [4]. Method SHS was used in [5] to obtain composites from $\mathrm{Ni}_{3} \mathrm{Al}$ with inclusions $\mathrm{TiC}, \mathrm{WC}, \mathrm{TaC}$, etc. Authors [6] studied the physical and chemical phenomena in the reaction of $\mathrm{TiO}_{2}, \mathrm{C}, \mathrm{Al}$ and the TiC/Alumina composite synthesis. Self sustaining high temperature synthesis (SHS) together with following disintegration is on of possible variant to obtain the powder systems with required structure for application for surface modification and object creation in additive technologies [7]. However irreversible conditions of the synthesis lead to the problems of theoretical and experimental character. For example, when the synthesis is carried out in the regime of layered combustion from the mixtures containing inert component (the component does not participate in the reaction), there is limiting concentration of inert above that reaction front stops. In the double systems $\mathrm{Ti}-\mathrm{C}, \mathrm{Ti}-\mathrm{Si}$, Ti-B, excess titanium powder should play a role of inert addition and should form titanium binder in the product. Dependencies of the maximal product temperature and combustion rate on the elemental composition of the green mixture were investigated in numerous papers; however detailed phase composition of the reaction product does not correspond to theoretical predictions. Temperature and combustion rate decrease monotonically when titanium content increase. Second feature inherent to all three systems consist in the liquid phase formation in the reaction front that play ambiguous role in the combustion mechanism. Reversible state diagram of Ti-C differs on two other systems because there is a wide area of homogeneity for titanium carbide shifted to titanium. This leads to the formation of nonstoichiometric titanium during the synthesis from powder mixtures with titanium excess instead the predicted composition Ti-TiC: instead 60 volume $\%$ of titanium binder real composition gives $26 \mathrm{~V} \%$ [8] of titanium. Several intermediate compounds present at the reversible state diagram for the systems Ti-Si, Ti-B (three borides and five silicides); however not all phases are observed experimentally after the synthesis.

To study the dynamics of reaction front formation, in this paper, the process of composites synthesis in the systems Ti-C, $\mathrm{Ti}-\mathrm{Si}$, Ti-B with $\mathrm{Ti}$ excess is investigated numerically in term of classical concept with summary reaction scheme taking into account reaction retardation with product accumulation in the special kinetical function.

\section{Problem formulation}

To calculate theoretically the combustion rate and product temperature in studied systems we use the model suggested in [9] adding it by the stage the reaction initiation in the igniter and properties dependence on the composition. Generalized model for three systems contains the thermal conductivity equations for igniter (stochiometric mixture $5 \mathrm{Ti}+3 \mathrm{Si}$ ) and for the mixture where composites form. Specimen is two-layer cylinder with radius $R$. First layer has the thickness $l$, second layer thickness is $L$ (Fig. 1).

The second mixture contains the Ti-excess with mass concentration $\eta_{e}$. In a first approximation, we assume that summary reactions correspond to simple reaction schemes

Ti $+\mathrm{C}$ titanium carbide,

or Ti+2B $\rightarrow$ titanium boride,

or $5 \mathrm{Ti}+3 \mathrm{Si} \rightarrow$ titanium silicide 
or summary scheme "Reagent-Product". Reaction initiation in the igniter is carried out by spark. Hence, for reaction depth description only two kinetical equations are necessary - for first and for second layers.

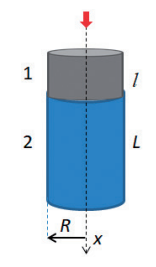

Fig.1. Illustration to the problem formulation: 1-igniter; 2. pressed-powder compact (reagent)

1. ábra Illusztráció a probléma értelmezéséhez: 1- a gyújtófej; 2. a préselt (reagens) test

As a result, we come to the mathematical model:

$c_{1} \rho_{1} \frac{\partial T_{1}}{\partial t}=\frac{\partial}{\partial x}\left(\lambda_{1} \frac{\partial T_{1}}{\partial x}\right)+Q_{1} \phi_{1}\left(\eta_{1}, T_{1}\right)-\frac{2 \alpha}{R}\left(T_{1}-T_{0}\right)-\frac{2 \varepsilon \sigma_{0}}{R}\left(T_{1}^{4}-T_{0}^{4}\right), \quad x \leq l ;$

$\frac{d \eta_{1}}{d t}=\phi_{1}\left(\eta_{1}, T_{1}\right)=z_{01}\left(1-\eta_{1}\right) \exp \left(-\frac{E_{a 1}}{R_{g} T_{1}}\right) \exp \left(-m_{1} \eta_{1}\right)$;

$c_{2} \rho_{2} \frac{\partial T_{2}}{\partial t}=\frac{\partial}{\partial x}\left(\lambda_{2} \frac{\partial T_{2}}{\partial x}\right)+Q_{2}\left(1-\eta_{e}\right) \phi_{2}\left(\eta_{2}, T_{2}\right)-\frac{2 \alpha}{R}\left(T_{2}-T_{0}\right)-\frac{2 \varepsilon \sigma_{0}}{R}\left(T_{2}^{4}-T_{0}^{4}\right), l<x<L$,

$\frac{d \eta_{2}}{d t}=\phi_{2}\left(\eta_{2}, T_{2}\right)=z_{02}\left(1-\eta_{2}\right) \exp \left(-\frac{E_{a 2}}{R_{g} T_{2}}\right) \exp \left(-m_{2} \eta_{2}\right)$;

$x=0: \lambda_{1} \frac{\partial T_{1}}{\partial x}=q_{0} \delta(t)$;

$x=l:\left\{\begin{array}{c}\lambda_{1} \frac{\partial T_{1}}{\partial x}=\lambda_{2} \frac{\partial T_{2}}{\partial x}, \\ T_{1}=T_{2} ;\end{array}\right.$

$x=L:-\lambda_{2} \frac{\partial T_{2}}{\partial x}=0$;

$t=0: \quad T_{1}=T_{2}=T_{0}, \eta_{1}=\eta_{2}=0$,

where index «1» relates to igniter, index «2» relates to the mixture under study, $T$ - is the temperature, $\eta_{\mathrm{k}}, k=1,2$, - is the product concentration or conversion level; $t$ - is the time; $x$ - is the spatial coordinate; $\lambda_{k}, c_{k}, \rho_{k}-$ are the effective thermal conductivity, - unwanted coefficients, heat capacities and densities depending on the current composition; $Q_{k}$ are chemical heats of summary reactions; $\alpha$ - is effective heat exchange coefficient in Newton law; $\sigma_{0}$ - is Stephen-Boltzmann constant; $\varepsilon_{0}$ - is blackness level; $\delta_{(t)}$ - is delta function; $E_{a k}-$ are activation energies; $z_{0 k}$ - pre-exponential factors; $m_{k}$ are the retardation coefficient in formal kinetical laws.

Titanium melting is taken into account through the heat capacity change. Then we can write

$(c \rho)_{T i}=\left\{\begin{array}{ll}(c \rho)_{s}, & T<T_{p h,} \\ (c \rho)_{L}, & T \geq T_{p h},\end{array}, Q_{p h} \rho_{s} \delta\left(T-T_{p h}\right)\right.$,

where indexes $s$ and $L$ correspond to the parameters of solid and liquid phases; $Q_{\mathrm{ph}}$ - is melting heat; $T_{\mathrm{ph}}$ - is melting temperature. Because the powder mixture structure changes during the synthesis and it is not known a priori, we restrict the effective properties calculation by mixture rule, for example, for first layer

$c_{1} \rho_{1}=\left[c_{T i} \rho_{T i} \eta_{T i}+c_{S i} \rho_{S i}\left(1-\eta_{T i}\right)\left(1-\eta_{1}\right)+c_{T i S S i 3} \rho_{T i 5 S i 3} \eta_{1}\right.$.

The problem was solved numerically. Temperature and concentration fields were found for different time moments that had allow to find the product temperature and combustion rate for different parameters of the model. The data presented in [10] where used for the calculation (Table 1). Formal-kinetical parameters that used for calculations are presented in Table 2 [10-13]. It was assumed: $l=1 \mathrm{~cm}, \mathrm{~L}=5 \mathrm{~cm}, \mathrm{R}=2.5 \mathrm{~cm}, \mathrm{a}=10^{3} \mathrm{~W} /$ $\left(\mathrm{m}^{2} \mathrm{~K}\right), \mathrm{s}=5.67 \times 10^{-8} \mathrm{~W} /\left(\mathrm{K}^{4} \mathrm{~m}^{2}\right)$. Other parameters are varied.

\begin{tabular}{|c|c|c|c|c|}
\hline Substance & $r_{s} / r_{L}, k g / m^{3}$ & $\lambda, W /\left(\mathbf{m}^{2} \mathbf{K}\right)$ & $c_{s} / c_{L}, J /(k g \times K)$ & $\mathbf{T}_{\text {melting }}, \mathbf{K}$ \\
\hline Ti & $4540 / 4120$ & 22 & $498 / 687$ & 1941 \\
\hline C(graphite) & 2250 & 1.6 & 712 & 4620 \\
\hline $\mathbf{S i}$ & $2330 / 2520$ & 150 & $690 / 979$ & 1687 \\
\hline B & 2340 & 27.4 & 1280 & 2075 \\
\hline TiC & 4900 & 21.9 & 696 & 3533 \\
\hline $\mathrm{Ti}_{5} \mathrm{Si}_{3}$ & 4320 & 26.8 & 140 & 2403 \\
\hline $\mathrm{TiB}_{2}$ & 4500 & 24 & 656 & 3503 \\
\hline $\begin{array}{l}\text { Table 1. Th } \\
\text { 1. táblázat Hón }\end{array}$ & tulajdon & & & \\
\hline
\end{tabular}

\begin{tabular}{|c|c|c|c|c|}
\hline Reaction & $\underset{(\mathrm{M} J / \mathbf{k g})}{\Delta \mathrm{H}_{\text {react }} \mathbf{K J} / \mathbf{m o l}}$ & $\mathrm{E}_{\mathrm{a}} \mathrm{kJ} / \mathrm{mol}$ & $k_{0}, 1 / s$ & $\begin{array}{c}\text { Molar mass, } \\
\mathrm{g} / \mathrm{mol}\end{array}$ \\
\hline$T i+C \rightarrow T i C$ & 209 (3.5) & 117 & $10^{8}$ & $60(\mathrm{TiC})$ \\
\hline $\mathrm{Ti}+2 \mathrm{~B} \rightarrow \mathrm{TiB}_{2}$ & $295.4(4.25)$ & 123.3 & $10^{8}$ & 69.5 \\
\hline $5 \mathrm{Ti}+3 \mathrm{Si} \rightarrow \mathrm{Ti}_{5} \mathrm{Si}_{3}$ & $579.3(1.8)$ & 204.2 & $10^{12}$ & $324\left(\mathrm{Ti}_{5} \mathrm{Si}_{3}\right)$ \\
\hline
\end{tabular}

Table 2. Kinetical parameters for the reactions 2. táblázat Reakció-kinetikai paraméterek

\section{Result analysis}

Reaction front coordinate $X_{\mathrm{p}}$ reaction front rate (combustion rate) $V_{\mathrm{f}}$ and thickness of the reaction zone $X_{\mathrm{ch}}$ were determined similarly to [14]. The retardation parameters were found based on experimental data. It was ascertained for all three systems $m_{2}=10$. The comparison of numerical results with experimental data (the experimental method was described, for example, in $[8,14])$ is presented in Fig. 2. For the systems Ti-Si, Ti-B the agreement is very well. For the system Ti-C, there is the deviation of theory from experiment that connects probably with reductive character of the model, where the existence of wide area of homogeneity is not taken into account. Second cause for the deviation connects obviously with the measure of the combustion temperature for the synthesis conditions in air. Titanium oxidation can effect on summary heat release that is confirmed with the data [9], where the presence of titanium dioxide to $8 \%$ was detected. With titanium excess $\eta_{e}$ increase the combustion temperature decreases.

Calculation for the reaction mixture $\mathrm{Ti}-\mathrm{B}$ show that the part of titanium excess $\eta_{e}$ affects only maximal temperature and this practically does not change the combustion rate (curve 2 in Fig. 2.b). 

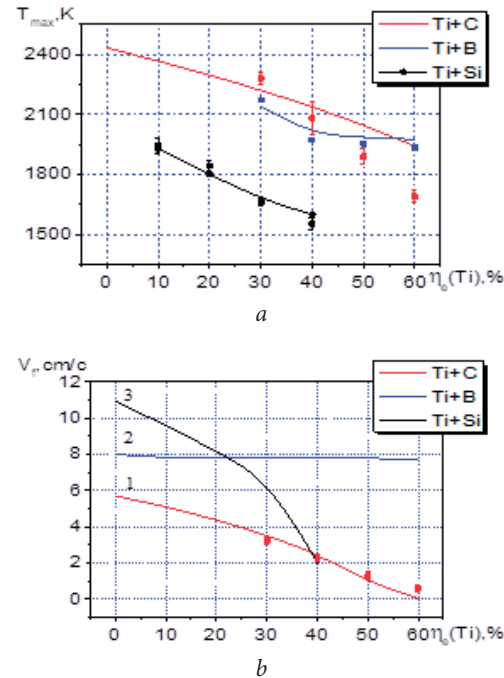

Fig. 2. The dependencies of maximal temperature (a) and reaction front propagation (b) on the titanium excess in green mixture. $m_{1}=10, q_{0}=1.3 \mathrm{MW} / \mathrm{m}^{2} m_{2}=10$; points - experimental data

2. ábra A nyers (zöld) keverékben a maximális hömérséklet (a) és az reakció (égési) frontvonal terjedése (b) a titánban $m_{1}=10, q_{0}=1,3 \mathrm{MW} / \mathrm{m}^{2}$; kisérleti adatok $m_{2}=10$

For various systems different combustion regimes were found. Typical qualitative picture for stationary combustion regime is presented in Figs. 3.a and 3.b. for the system $\mathrm{Ti}+\mathrm{Si}$. For chosen composition, the reaction proceeds in the solid phase, melting temperature is not achieved. For $\eta_{\mathrm{e}}=40 \%$, the periodic regimes could be observed: after some reaction front delay, reaction can be renewed. This did not be observed for other systems. To demonstrate the difference in the combustion regimes, maximal temperature and average conversion versus time level are suitable. Average conversion level is calculated by the formula

$\eta_{\Sigma}(t)=\frac{1}{(L-l)} \int_{l}^{L} \eta(x, t) d x$.
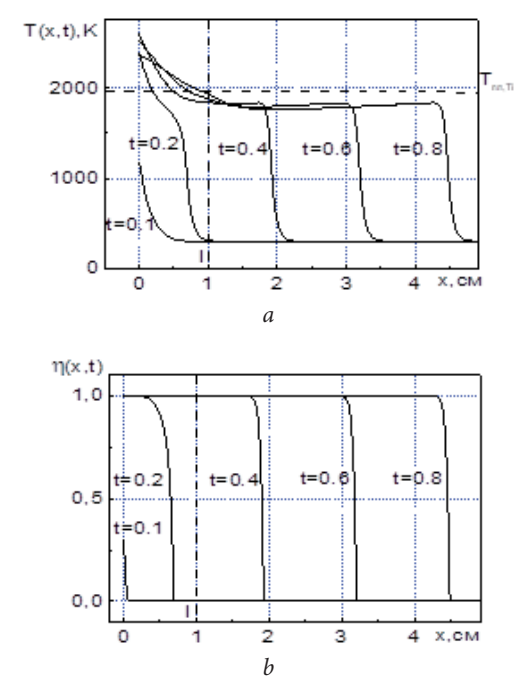

Fig. 3. Temperature (a) and conversion level ( $b$ ) for the stationary combustion regime. $\eta_{e}=20 \% ; q_{0}=1.3 \mathrm{MW} / \mathrm{m}^{2}$, system Ti+Si; time moments: $t=1.0 .1 ; 2$. $0.2 ; 3.0 .4 ; 4.0 .6 ; 5.0 .8 ; 6.2 .95 \mathrm{~s}$

3. ábra A hömérsékler (a) és a konverziós szint (b) stacionáris égési rendszer esetén a Ti-Si anyagrendszerben. $\eta_{e}=20 \% ; q_{0}=1,3 \mathrm{MW} / \mathrm{m}^{2}$; idő pillanatok: $t=1.0,1$; 0,$2 ; 3.0,4 ; 4.0 .6 ; 5,8 ; 6,2,95 s$
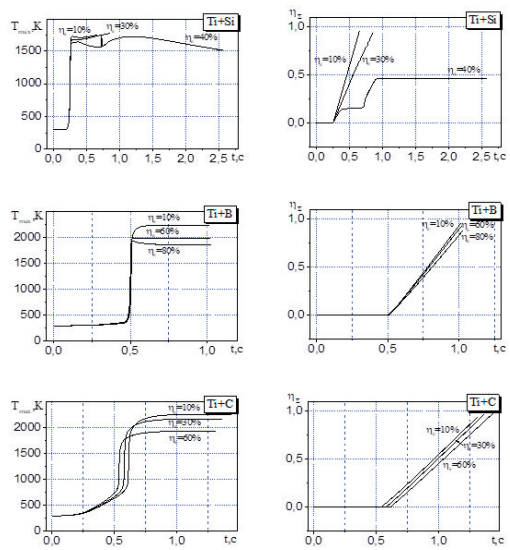

Fig. 4. Maximal temperature and average conversion level versus time for various systems

4. ábra A maximális hömérséklet és az átlagos konverziós szint az eltérő titán alapú anyagrendszerekben

The results are presented in the Fig. 4. For the system TiSi (Fig. 4.a), practically stationary regimes with various rates are observed for $\eta_{e}=10$ and 30\%. Maximal temperature is not constant, the rate of the reaction front propagation can be determined as the slope of the curve $\eta_{\Sigma}(t)$. If $\eta_{e}=40 \%$, the phenomena of the repeated reaction initiation takes place, but after $\eta_{\Sigma}(t) \approx 0,49$ reaction stops. Reaction front coordinate is presented in Fig. 5 for various regimes. Quasistaionary regime with total conversion was found only for $\eta_{e}=10 \%$. 5; for $\eta_{e}=$ $80 \%$, the repeated reaction initiation does not occur.

For the system Ti-B (Fig. 4.b), the quasistaionary regimes are characterized by different maximal temperatures. The reaction front rate determined as in [14] does not change; the reaction front rate determined as the slope of the curve $\eta_{\Sigma}(t)$ decrease very weakly. If $\eta_{e}=10 \%$, maximal temperature grows slowly to stationary value when qusisiationary regime establishes; if $\eta_{e}$ $=40 \%$, combustion temperature reaches to maxima and then diminishes to stationary value.

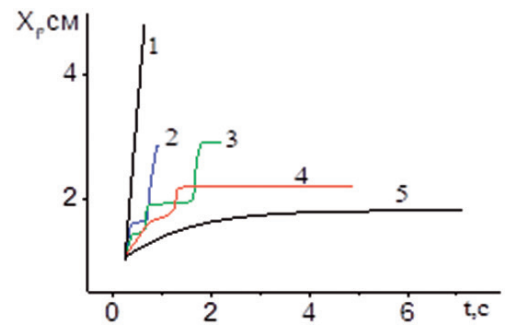

Fig.5. Reaction front coordinate versus time for the system Ti-Si; $m_{1}=10, m_{2}=10, q_{0}=1.3 \mathrm{MW} / \mathrm{m}^{2}$ Curves: $1.10 \% ; 2.40 \% ; 3.50 \% ; 4.60 \% ; 5.80 \%$

5. ábra A reakció frontvonal terjedése az idö függvényében a Ti-Si rendszerben, $m_{1}=10, m_{2}=10, q_{0}=1,3 \mathrm{MW} / \mathrm{m}^{2}$

Konverziós szintek:: 1. 10\%; 2. 40\%; 3. 50\%; 4. 60\%; 5. 80\%

For the system Ti-C (Fig. 4.c), the rize of titanium excess leads to the reaction zone expansion, quick maximal temperature decrease, however the reaction starts earlier. Reaction front rate decreases, if it is determined by the method [14], however it does not change, if it calculated as the slope of the curve $\eta_{\Sigma}(t)$. To understand the difference in the physical mechanism of the synthesis and the reaction front propagation the additional experimental and theoretical study are necessary. 


\section{Conclusions}

So, the solid-phase combustion model with summary reaction scheme was realized numerically for three systems: titanium-carbon, titanium-boron, titanium-silicon. Taking into account nonstoichiometric composition of initial powder mixture, reaction retardation by reaction product, and dependence of properties on composition, the qualitative compliance between theory and experiment was obtained. The various combustion regimes for different systems were detected. Following study should include the detailed reaction scheme corresponding to irreversible conditions and porosity evolution during composite synthesis.

\section{Acknowledgements}

This work was presented in the 3rd International Conference on Rheology and Modeling of Materialsand was supported by Russian Science Foundation (RSF), grunt number 17-19-01425.

\section{References}

[1] Merzhanov, A. G. (2003): Combustion and explosion processes in physical chemistry and technology of inorganic materials. Russian Chemical Reviews, Vol. 72, No 4, 2003, pp. 289 - 310. https://doi.org/10.1070/RC2003v072n04ABEH000766

[2] Rogachev, Alexander S. - Mukasyan, Alexander S. (2015): Combustion for Material Synthesis, Taylor Francis Group, $424 \mathrm{P}$

[3] Mas-Guindal M. J., - Contreras, L. - Turrillas, X. - Vaughan, G.B.M. Kvick, A. - Rodriguez, M. A. (2006): Self-propagating high-temperature synthesis of TiC-WC composite materials. Journal of Alloys and Compounds, Vol. 419, 2006, pp. 227-233 https://doi.org/10.1016/j.jallcom.2005.08.079

[4] Yang, Y. F. - Jiang, Q. C. (2013): Reaction behaviour, microstructure and mechanical properties of $\mathrm{TiC}-\mathrm{TiB} 2 / \mathrm{Ni}$ composite fabricated by pressure assisted self-propagating high-temperature synthesis in air and vacuum. Materials and Design, Vol.49 August 2013, pp. 123-129 https://doi.org/10.1016/j.matdes.2013.02.036

[5] Fra, E. - Janas, A. - Kolbus, A. - Olejnik, E. (2009): Cast in situ composites of $\mathrm{Ni}_{3} \mathrm{Al} / \mathrm{MeC}$ type. Archives of foundry engineering, Vol. 9, Is. 2. 2009. pp.81-86

[6] Ahmed, Y. M. Z. - Zaki, Z. I. - Bordia, R. K. - Besisa, D. H. A. - Amin, A. M. M. (2016): Simultaneous synthesis and sintering of $\mathrm{TiC} / \mathrm{Al}_{2} \mathrm{O}_{3}$ composite via self propagating synthesis with direct consolidation technique, Ceramics International, Vol. 42, 15 November, 2016, pp.1658916597 https://doi.org/10.1016/j.ceramint.2016.07.080

[7] Sutton, Austin T. - Kriewall, Caitlin S. - Leu, Ming C. - Newkirk, Joseph W. (2016): Powders for additive manufacturing processes: characterization techniques and effects on part properties - Solid Freeform Fabrication 2016: Proceedings of the 26th Annual International Solid Freeform Fabrication Symposium - An Additive Manufacturing Conference; The Department of Energy's Kansas City National Security Campus is operated and managed by Honeywell Federal Manufacturing Technologies, LLC under contract number DE-NA0002839. Virtual and Physical Prototyping, V. 12, 2017, Is. 1 pp.3-29
[8] Pribytkov, G. A. - Krinitcin, M. G. - Korzhova, V. V. (2016): Investigation of the products of $\mathrm{SH}$-synthesis in powder mixture of titanium and carbon (in Russian), Perspective materials, 2016, №5, P. 59-68

[9] Strunina, A. G. - Firsov, A. N. - Kostin, S. V. (1981): Transition modes in the combustion of heterogeneous systems with solid-phase products, Combustion, Explosion and Shock Waves, 1981, V. 17, Is. 5, pp. 500-505 https://doi.org/10.1007/BF00798134

[10] Babichev, A. P. - Babushkina, N. A. - Bratkovskii, A. M. (1991): Physical values: reference book (in Russian), Grigoriev I.S., Meilikhova M. - eds. / M.: Energoatomizdat, 1991. 1232 pp.

[11] Yeh, C. L. - Chen, W. H. - Hsu, C. C. (2007): Formation of titanium silicides $\mathrm{Ti} 5 \mathrm{Si} 3$ and $\mathrm{TiSi} 2$ by self-propagating combustion synthesis, Journal of Alloys and Compounds, 2007, Vol. 432, Is.1-2, pp. 90-95. https://doi.org/10.1016/j.jallcom.2006.05.131

[12] Capaldi, M. J. - Said, A. - Wood, J. V. (1997): Reaction Synthesis of TiC and Fe-TiC composites, ISIJ International, 1997, Vol. 37. № 2, pp. 188-193. https://doi.org/10.2355/isijinternational.37.188

[13] Kartal, G. - Timur, S. (2013): Growth kinetics of titanium borides produced by CRTD-Bor method. Surface \& Coatings Technology, 2013, Vol. 215, pp. 440-446. https://doi.org/10.1016/j.surfcoat.2012.08.076

[14] Chumakov, Yu. A. - Knyazeva, A. G. - Pribytkov, G. A. (2017): Synthesis of the composites on the base of titanium in the combustion mode (in Russian), Chemical physics and mesoscopy. 2017, V.19, № 4. - pp.

\section{$\underline{\text { Ref.: }}$}

Knyazeva, A. G. - Pribytkov, G. A. - Chumakov, Yu. A.: Titaniumbased composite synthesis in the combustion regime Építőanyag - Journal of Silicate Based and Composite Materials, Vol. 70, No. 3 (2018), 74-77. p. https://doi.org/10.14382/epitoanyag-jsbcm.2018.13

\section{Titán alapú kompozít szintézise égési rendszerben}

Jelen munkában a szerző́k numerikusan modelezik a karbid, borid és szilicid zárványokat tartalmazó titán alapú kompozit szintézisét. modellje numerikusan valósul meg. Feltételezik, hogy a fém titán többletet tartalmazó Ti-C, Ti-B és Ti-Si porkeverékek termikus szintetizálása során sztöchiometrikusan képzôdnek a TiC, TiB és $\mathrm{Ti}_{5} \mathrm{Si}_{3}$ komponensek - létrehozva ezáltal egy új kompozít anyagszerkezetet. Az általuk alkalmazott mốdszer az „égetố modellek” klasszikus ötletén alapszik, ahol a kémiai átalakulások és reakciók mint a „köz vetlen égés" eredménye mennek végbe. Mindazonáltal az alkalmazott módszer figyelembe veszi a nyers (zöld) keverék nem-sztöchiometrikus összetételét, a tulajdonságok függését a szintézis során változó összetételre és a gyújtóreakció kezdeti szakaszára. A hômérséklet-eloszlást, a konverziós szintet, a maximális égési hômérsékletet, a reakciózónák vastagságát és a reakció terjedésének sebességét numerikusan határozzák meg. A termék-hômérséklet számítás kapott eredményei minôségi szempontból jól megegyeznek a mért kísérleti adatokkal.

Kulcsszavak: kompozit szintézis, nem-sztöchiometrikus keverék, gázmentes égés, reakciókésleltetés reakciótermékkel, égés átmenet határfelületen

\section{PlasticsEurope}
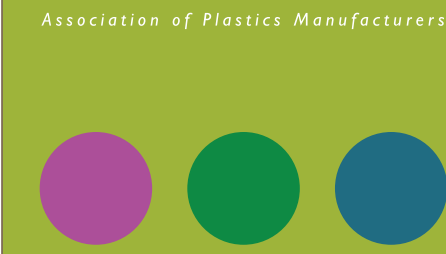

PlasticsEurope is one of the leading European trade associations with centres in Brussels, Frankfurt, London, Madrid, Milan and Paris. We are networking with European and national plastics associations and have more than 100 member companies, producing over 90\% of all polymers across the EU28 member states plus Norway, Switzerland and Turkey. 